\title{
Benign Adult Brain Neoplasm
}

National Cancer Institute

\section{Source}

National Cancer Institute. Benign Adult Brain Neoplasm. NCI Thesaurus. Code C5116.

A benign neoplasm of the brain occurring in adults. 